\title{
Clinical Classification and Severity Scoring Systems in Chronic Pancreatitis: A Systematic Review
}

\author{
Abidur Rahman $^{a}$ Donal B. O'Connor ${ }^{a}$ Felix Gather $^{\mathrm{a}}$ Sarah Koscic $^{\mathrm{a}}$ \\ Joshua Gilgan $^{\mathrm{a}}$ David Mockler $^{\mathrm{b}}$ Yasir Bashir ${ }^{\mathrm{a}}$ Robert Memba ${ }^{\mathrm{a}, \mathrm{c}}$ \\ Sinead N. Duggan ${ }^{a}$ Kevin C. Conlon ${ }^{a}$ \\ ${ }^{a}$ Department of Surgery, Tallaght University Hospital, Trinity College Dublin, Dublin, Ireland; ${ }^{b}$ Medical Library, \\ Trinity College Dublin, Dublin, Ireland; ' Department of HPB Surgery, Hospital Universitari Joan XXIII de Tarragona, \\ Tarragona, Spain
}

\section{Keywords}

Chronic pancreatitis $\cdot$ Severity score $\cdot$ Clinical classification

\begin{abstract}
Introduction: Chronic pancreatitis (CP) is characterised by pain, functional deficits, nutritional and mechanical complications. Frequently managed in out-patient settings, the clinical course is unpredictable and requires multi-disciplinary care. There remains substantial variation in management. In contrast to acute pancreatitis, there are no globally accepted classification or severity scores to predict the disease course or compare interventions. We conducted a systematic review to determine the scope and clinical use of existing scoring systems. Methods: A systematic search was developed with a medical librarian using the Embase, Medline and Cochrane databases. Original articles and conference abstracts describing an original or modified classification or scoring system in CP that stratified patients into clinical and/or severity categories were included. To assess clinical application/validation, studies using all or part of a score as a stratification tool to measure another parameter
\end{abstract}

๑) 2019 S. Karger AG, Basel or outcome were selected. Studies reporting on diagnosis or aetiology only were excluded. Four authors performed the search in independent pairs and conflicts were resolved by a fifth author using Covidence ${ }^{\mathrm{TM}}$ systematic review software. Results: Following screening 6,652 titles and 235 full-text reviews, 48 papers were analysed. Eleven described original scores and 6 described modifications of published scores. Many were comprehensive but limited in capturing the full spectrum of disease. In 31 studies, a score was used to categorise patients to compare or correlate various outcome measures. Exocrine and endocrine dysfunction and pain were included in 6,5 , and 4 scoring systems, respectively. No score included other nutrition parameters, such as bone health, malnutrition, or nutrient deficiency. Only one score has been objectively validated prospectively and independently for monitoring clinical progression and prognosis, but this had been applied to an in-patient population. Conclusion: Available systems and scores do not reflect recent

A.R. and D.B.O.C. contributed equally to the manuscript. 
advances and guidelines in $\mathrm{CP}$ and are not commonly used. A practical clinical classification and scoring system, validated prospectively for prognostication would be useful for the meaningful analysis in observational and interventional studies in CP.

(C) 2019 S. Karger AG, Basel

\section{Introduction}

Chronic pancreatitis (CP) is a heterogeneous, progressive inflammatory chronic disease. It is characterised by abdominal pain, irreversible pancreatic morphological changes, loss of exocrine and endocrine pancreatic function, nutritional and mechanical complications [1-5]. The overall incidence of CP in Europe is 5-10 per 100,000, and there are data to suggest that the incidence is increasing [6-8]. Whilst the majority of cases from western countries have been attributed to alcohol excess, it is now recognised to have a multifactorial aetiology [9]. The clinical manifestations demonstrate a wide spectrum of disease, and the clinical course and disease progression can be unpredictable. There have been significant developments in understanding the aetiology and substantial improvements in the diagnosis and treatment of this complex disease but there remains substantial variation in its management. In contrast to acute pancreatitis, there are no globally accepted or frequently used clinical classification or severity scoring systems for monitoring the clinical course or comparing interventions. Cambridge and Rosemont are widely known diagnostic classifications but are based on morphological changes only without clinical correlation, and the comprehensive TIGAR-O classification of aetiology does not stage the clinical manifestations [10-12].

Recently published evidence-based guidelines from the working group on "Harmonising diagnosis and treatment of CP across Europe" noted that there is no "preferred classification system for defining the aetiology of $\mathrm{CP}$ since the available classification systems need to be evaluated in randomised prospective trials" [6]. Contemporary clinical practice updates from North America also have not incorporated the use of clinical classification systems [13]. The Harmonising diagnosis and treatment of CP across Europe working group acknowledged that classification systems are of great importance for guiding the management of CP. Furthermore, treatment decisions should not be based solely on morphology, which is the limitation of the Cambridge system and various others using diagnostic imaging, but should incorporate clinical and functional complications of the disease. This is particularly important in areas with clinical equipoise such as selection of patients for surgery, choice of procedure, and timing of surgical interventions [14].

The aims of this systematic review were to (i) identify published clinical classification or severity scoring systems in CP, (ii) identify evidence of their use in clinical practice or research, and (iii) qualitatively assess if the studies reflected the full spectrum of disease incorporating aetiology and reflecting the modern understanding of disease complications across major categories of pain, functional loss (exocrine and endocrine), and pancreatic and extra-pancreatic mechanical complications.

\section{Methods}

Systematic Literature Search

A systematic search of the Embase, Medline and Cochrane databases for CP and "classification, scoring, prediction" systems was performed to include all articles from 1950 until May 5, 2018 (Appendix for MeSH terms). The search was restricted to studies in adult humans. In addition, major pancreatic meeting abstracts were reviewed for the years 2016 up to June 2018.

The studies selected based on the search strategy were uploaded into the online program Covidence ${ }^{\mathrm{TM}}$ (Covidence systematic review software, Veritas Health Innovation, Melbourne, Australia). Following title and abstract screening, full papers were retrieved to complete a full text review to determine the papers that were selected for analysis. When conference proceedings were available, the study was assessed if sufficient information was presented. If a score was reported more than once, the most recent publication was selected. Title screening and full text review were performed in duplicate by 2 pairs of authors and any conflicts were resolved by an independent 5th author. PRISMA guidelines for reporting were followed in systematic reviews.

\section{Selection Criteria}

Original articles or conference proceedings in English, which described any attempt to stratify patients with CP into a clinical and/or severity category, were included. To assess clinical application or validation, studies using all or part of a selected score as a stratification tool to measure another parameter or outcome were also included. Studies were excluded if (1) the scoring systems involved other conditions not specific to $\mathrm{CP},(2)$ they stratified patients but did not categorise a clinical stage or correlate the scoring system to any other parameter (e.g., the classification had been used only for aetiology or diagnosis).

\section{Results}

\section{Search Results}

The search yielded 6,652 titles. Following title and abstract screening, 235 full-text reviews were conducted and 48 papers were ultimately included in the systematic review (Fig. 1 for complete search results). 


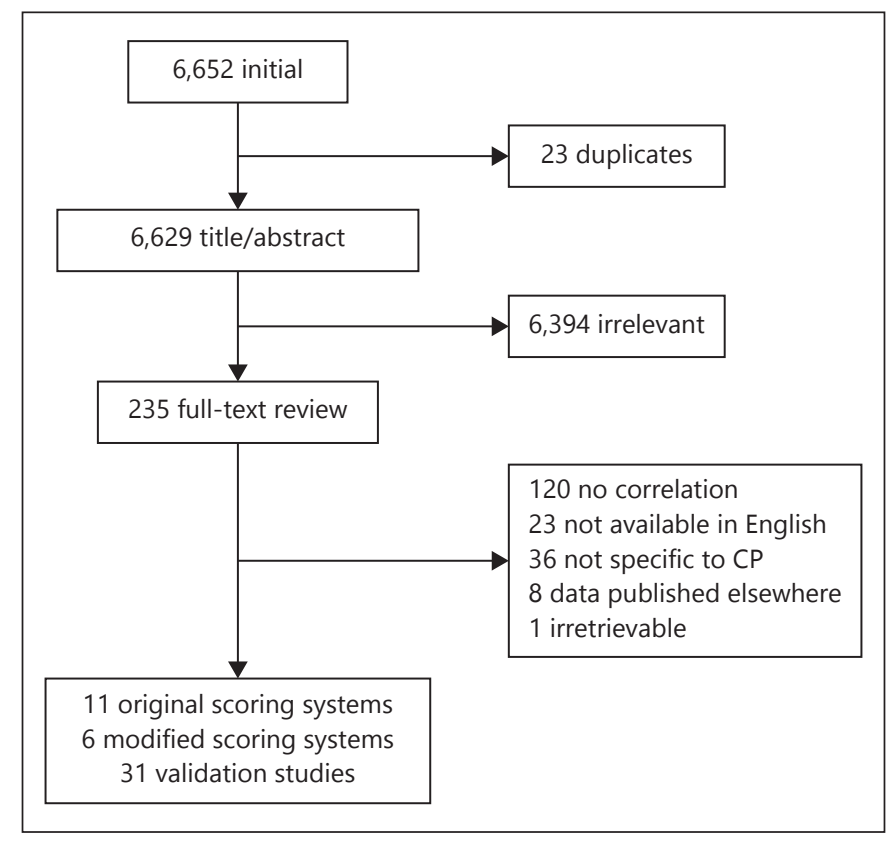

Fig. 1. PRISMA flow diagram for search strategy used in the systematic review of chronic pancreatitis (CP) classification and scoring systems.

\section{Original Scoring Systems [10, 14-23]}

Eleven studies described original scores that collected patient parameters to classify patients into severity groups or clinical stages (or to assign a score for severity). The studies included a minimum of 2 parameters (Table 1). Pancreatic morphology and peri-pancreatic complications (including biliary stricture, duodenal stenosis, and portal vein thrombosis) were the most commonly used feature (included in 7 of 11 papers). Exocrine and endocrine dysfunctions and pain were also commonly used and were included in 6,5 , and 4 scoring systems, respectively. Three systems included interventions as a parameter (Table 1). Aetiology was generally not correlated to clinical severity, but definitions of aetiology were classified in 4 studies. No systems included indices of nutritional status, such as malnutrition, nutrient deficiency or bone health.

\section{Modified Scoring Systems [24-29]}

The search yielded 6 studies, which applied substantial modification to an original CP scoring system (Table 2). The Cambridge classification was the most frequently adapted system despite not being originally designed as a clinical severity score. The most common modification involved the addition of other parameters to broaden the clinical scope of the system such as, including exocrine dysfunction or aetiological risk factors. These modified scoring systems were typically used to form comparator groupings within each study without specific proposals for further application.

Validation Studies of Existing Scoring Systems [30-60]

An application or validation of an original scoring system was reported in 31 studies (Table 3 ). The Cambridge classification (either in its original form applied to endoscopic retrograde cholangiopancreatography or adapted for other imaging modalities such as computed tomography) featured in 16 papers. The M-ANNHEIM classification was partially applied in eleven studies. As the Cambridge classification was designed as a diagnostic tool without intent for scoring clinical severity, it did not fit our inclusion criteria as an original scoring system. However, many studies adopted the Cambridge classification. The most common application, both with the Cambridge score and overall, was the use of imaging to stratify patients into groups for comparison or correlation of a single functional measurement, for example, exocrine dysfunction. The degree of correlation reported between imaging findings and other clinical or functional parameters was highly variable.

The M-ANNHEIM classification has been applied to predict the clinical course and need for operative intervention. The majority of studies utilized only a single component of the M-ANNHEIM system instead of the full tool as was originally presented.

\section{Discussion/Conclusion}

This systematic review identified various classification systems for CP, but there is limited evidence of their application in clinical practice or clinical studies. This is in contrast to the situation in acute pancreatitis where scoring systems such as Glasgow and Ranson are routinely applied in patient management as part of best practice and also as a covariate in clinical studies $[61,62]$. Furthermore, in other chronic diseases that require medical and surgical interventions such as colitis, the Mayo score is frequently applied in therapeutic guidance or escalation of care [63]. To improve the clinical management of CP and to reflect the advances in understanding of genetic, aetiological, and functional characteristics of the disease, a classification system based on the key clinical aspects is desirable. Any severity score derived from such a classification should be simple to apply, objective, and accurate for observing progression of disease or comparing interventions. 
Table 1. Original clinical classification or severity scoring systems

\begin{tabular}{|c|c|c|c|c|c|c|c|c|c|c|c|c|}
\hline $\begin{array}{l}\text { Study } \\
\text { author }\end{array}$ & Name & Year & $\begin{array}{l}\text { Class } \\
\text { categories }\end{array}$ & Aetiology & Morphology & $\begin{array}{l}\text { Endocrine } \\
\text { function }\end{array}$ & $\begin{array}{l}\text { Exocrine } \\
\text { function }\end{array}$ & $\begin{array}{l}\text { Nutritional } \\
\text { features }\end{array}$ & Pain & Complications & Intervention & Other \\
\hline $\begin{array}{l}\text { Stern } \\
\text { et al.[15] }\end{array}$ & & 1982 & $\begin{array}{l}\text { Minimal, } \\
\text { moderate, } \\
\text { severe }\end{array}$ & No & Yes & Yes & Yes & No & No & Yes & Yes & No \\
\hline $\begin{array}{l}\text { Catalano } \\
\text { et al. [16] }\end{array}$ & & 1998 & $\begin{array}{l}\text { Mild, moderate, } \\
\text { severe }\end{array}$ & Yes & Yes & No & Yes & No & No & No & No & No \\
\hline $\begin{array}{l}\text { Gullo } \\
\text { et al. [17] }\end{array}$ & & 1999 & $\begin{array}{l}\text { Mild, moderate, } \\
\text { severe }\end{array}$ & Yes & Yes & No & No & No & No & No & No & No \\
\hline $\begin{array}{l}\text { Ramesh } \\
\text { et al. [18] }\end{array}$ & $\begin{array}{l}\text { The ABC } \\
\text { system }\end{array}$ & 2002 & $\begin{array}{l}\text { A, B, C } \\
\text { (increasing in } \\
\text { severity, } \\
\text { subdivided) }\end{array}$ & No & No & Yes & Yes & No & Yes & Yes & No & No \\
\hline $\begin{array}{l}\text { Bagul } \\
\text { et al. [19] }\end{array}$ & Manchester & 2006 & $\begin{array}{l}\text { Mild, moderate, } \\
\text { end-stage }\end{array}$ & No & Yes & Yes & Yes & No & Yes & $\mathrm{Y}$ & No & No \\
\hline $\begin{array}{l}\text { Schneider } \\
\text { et al. [9] }\end{array}$ & MANNHEIM & 2007 & $\begin{array}{l}\text { Aetiology } \\
\text { (ANNHEIM), } \\
\text { Clinical stage } \\
\text { (Oabc, Iabc, } \\
\text { IIabc, IIIab, } \\
\text { IVab), Severity } \\
\text { (Minor, Increased, } \\
\text { Advanced, } \\
\text { Marked, } \\
\text { Exacerbated - } \\
\text { point based) }\end{array}$ & Yes & Yes & Yes & Yes & No & Yes & Yes & Yes & No \\
\hline $\begin{array}{l}\text { Orlikov } \\
\text { et al. [20] }\end{array}$ & CPI & 2007 & $\begin{array}{l}\text { Pancreatic } \\
\text { index score 1-3 }\end{array}$ & No & Yes & No & No & No & No & Yes & No & No \\
\hline $\begin{array}{l}\text { Büchler } \\
\text { et al. [14] }\end{array}$ & & 2009 & $\begin{array}{l}\text { Aetiology + } \\
\text { stages A, B, } \\
\text { and C }\end{array}$ & Yes & No & Yes & Yes & No & Yes & Yes & No & $\begin{array}{l}\text { Attack of } \\
\text { acute } \\
\text { pancreatitis }\end{array}$ \\
\hline $\begin{array}{l}\text { Naniwadekar } \\
\text { et al. [21] }\end{array}$ & $\begin{array}{l}\text { CP severity } \\
\text { index }\end{array}$ & 2011 & $\begin{array}{l}\text { CP severity score } \\
0 \text { (most severe) to } \\
1 \text { (not severe) }\end{array}$ & No & Yes & No & No & No & No & Yes & No & $\begin{array}{l}\text { Y - alcohol } \\
\text { use }\end{array}$ \\
\hline $\begin{array}{l}\mathrm{He} \\
\text { et al. [22] }\end{array}$ & & 2014 & $\begin{array}{l}\text { Numerical score } \\
\text { (scale unknown) }\end{array}$ & No & No & No & No & No & No & No & Yes & $\begin{array}{l}5 \text { drugs, } 2 \\
\text { procedures, } \\
1 \text { admission } \\
\text { characteristic }\end{array}$ \\
\hline $\begin{array}{l}\text { Beyer } \\
\text { et al. [23] }\end{array}$ & COPPS & 2017 & $\begin{array}{l}\text { Numerical score } \\
\text { categorised into } \\
3 \text { groups: } \\
\text { A (5-6 points) } \\
\text { B ( } 7-9 \text { points) } \\
\text { C (10-15 points) }\end{array}$ & Yes & No & Yes & No & No & Yes & No & No & $\begin{array}{l}\text { Thrombocyte } \\
\text { count, BMI, } \\
\text { and CRP } \\
\text { levels }\end{array}$ \\
\hline
\end{tabular}

The Cambridge classification established discrete categories of severity based on morphological changes. It has been adapted for computed tomography for wider application [10]. More recently, the Rosemont criteria has been described using EUS technology for diagnostic classification [11]. While they are important for diagnosis, there is limited correlation between morphology and clinical symptoms or functional deficits. Studies have indicated that patients with similar imaging findings can exhibit a wide variation of pain severity and patterns [64]. The TIGAR-O system includes all major aspects of aetiology, including genetic and auto-immune, but it does not describe clinical stages or severity [12]. Categorising patients by aetiology is clinically important and could be used to predict the clinical course of CP if incorporated into a system, for example, that included clinical complications.

The ABC, Manchester, and Heidelberg systems classify patients based on discrete clinical features into 3 severity stages. They are designed to be easy to use in clinical practice and reflected the advances in knowledge at the time of their development. The Manchester and $\mathrm{ABC}$ systems are similar and have been applied retrospectively to show some correlation with disease pro- 
Table 2. Modified scoring systems

\begin{tabular}{llll}
\hline Study author & Year & System modified & Modifications \\
\hline Jones [24] & 1988 & Cambridge & Revised morphological characteristics \\
\hline Bozkurt et al. [25] & 1994 & Cambridge & Revised morphological characteristics \\
\hline Yasuda et al. [26] & 2008 & $\begin{array}{l}\text { Japan Pancreas Society } \\
\text { Imaging Criteria 2001 }\end{array}$ & $\begin{array}{l}\text { Imaging criteria combined with exocrine function, } \\
\text { glucose metabolism, pain, alcohol intake, and complications }\end{array}$ \\
\hline Akisik et al. [27] & 2009 & Cambridge & $\begin{array}{l}\text { Imaging criteria combined with pain, endocrine/exocrine } \\
\text { dysfunction, prior episodes of pancreatitis }\end{array}$ \\
\hline Stevens et al. [28] & 2012 & Rosemont & $\begin{array}{l}\text { Imaging criteria combined with pain, typical CP risk } \\
\text { factors, exocrine function, history of acute pancreatitis }\end{array}$ \\
\hline Bahuva et al. [29] & 2013 & Rosemont & Revised imaging criteria and combined across modalities \\
\hline
\end{tabular}

gression. The staging proposed by Büchler et al. [14] has been used to demonstrate which clinical stages and complications were most likely to have been associated with surgical intervention. These systems do not facilitate classification of the full spectrum of clinical presentation. Also they classify patients with exocrine insufficiency as severe or end-stage, and it has become apparent that exocrine dysfunction can occur much earlier in the course of CP than previously considered, in particular in patients in whom CP develops following acute severe AP $[65,66]$. Furthermore, these systems do not account for the clinically important sequelae of mild or moderate pancreatic exocrine insufficiency, such as fat-soluble vitamin malabsorption and osteopathy [6].

The M-ANNHEIM system appears to be the most comprehensive tool available. It incorporates detailed diagnostic criteria, appropriately includes a multifactorial risk factor classification, and presents a severity score for grading of the clinical stage. Although expansive, the scoring system does not account for important sequelae of functional pancreatic insufficiency such as malnutrition, reduced bone mineral density, and type $3 c$ diabetes $[67,68]$. It has been applied retrospectively to demonstrate that patients with an earlier stage had a better outcome from endoscopic therapy for pain control [54]. The highly detailed format arguably limits application to routine clinical practice, and it has not been validated prospectively for use in predicting important clinical outcomes.

The most recently published score, CP Prognosis Score, has been prospectively validated to be able to predict important outcomes [23]. During the development of CP Prognosis Score, an array of biochemical and clinical parameters were analysed in patients with an unequivocal diagnosis of CP [23]. Bivariate correlations were determined and the resulting system accurately discriminated patients into stages of disease severity from low to high and predicted risk for hospitalisation and length of stay. The system was also validated in an independent external cohort. Although this scoring system was developed prospectively, it was applied almost exclusively to hospitalised patients. As patients with $\mathrm{CP}$ are often managed in the outpatient clinic setting, the predictive value may therefore be most relevant to patients at the extreme end of the severity spectrum. It is certainly a useful prediction model and has parallels with the Child-Pugh score for decompensated liver disease, but it does not incorporate a descriptive staging based on clinical characteristics.

The aforementioned scoring systems assist in the categorisation of CP patients, however, each having individual deficiencies. A comprehensive scoring system will allow for patients to be categorised according to disease severity, and therefore allow for appropriate treatment designations. In relation to pain, the patient's score should reflect if the patient has required pain-specialist intervention or is refractory to medical therapy including opiates and other adjuncts such as nerve blocks. Studies have indicated that majority of the patients with $\mathrm{CP}$ will require surgery for the disease, however, surgery is not indicated in most centres until there is significant increase in pain $[69,70]$. A scoring system which is clinically relevant should accurately stratify patients into disease severity and could be applied to randomised trials or prospective studies looking to answer areas of equipoise such as optimal surgery or timing of surgical interven- 
Table 3. Studies applying or validating scoring systems

\begin{tabular}{|c|c|c|c|c|c|}
\hline Author & Year & $\begin{array}{l}\text { System being } \\
\text { validated }\end{array}$ & $\begin{array}{l}\text { Total } \\
\text { (\# with CP), n }\end{array}$ & Method of validation & Result of validation \\
\hline $\begin{array}{l}\text { Itoh } \\
\text { et al. [30] }\end{array}$ & 1988 & Cambridge & 43 (28 with CP) & $\begin{array}{l}\text { Patients grouped by ERCP; } \\
\text { compared for differences in } \\
\text { gallbladder ejection fraction }\end{array}$ & $\begin{array}{l}\text { No difference in GBEF } \\
\text { between groups }\end{array}$ \\
\hline $\begin{array}{l}\text { Nagai } \\
\text { et al. [31] }\end{array}$ & 1993 & $\begin{array}{l}\text { Japanese } \\
\text { Society of } \\
\text { Gastroenterology } \\
\text { ERCP criteria }\end{array}$ & 40 (27 with CP) & $\begin{array}{l}\text { Patients grouped by ERCP; } \\
\text { compared for basal plasma } \\
\text { lipase, CRP, human pancreatic } \\
\text { polypeptide }\end{array}$ & $\begin{array}{l}\text { CRP and HPP correlated } \\
\text { to severity }\end{array}$ \\
\hline $\begin{array}{l}\text { Von Tirpitz } \\
\text { et al. [32] }\end{array}$ & 1998 & $\begin{array}{l}\text { Unknown } \\
\text { ERCP } \\
\text { Guidelines }\end{array}$ & 28 (18 with CP) & $\begin{array}{l}\text { Patients grouped by ERCP; } \\
\text { compared for endocrine function }\end{array}$ & $\begin{array}{l}\text { Close correlation with functional } \\
\text { endocrine reserve. No correlation } \\
\text { with endocrine stimulation } \\
\text { testing }\end{array}$ \\
\hline $\begin{array}{l}\text { Maartense } \\
\text { et al. [35] }\end{array}$ & 2004 & Cambridge & 103 (103 with CP) & $\begin{array}{l}\text { Patients grouped by US/CT/ } \\
\text { ERCP; compared for exocrine } \\
\text { function }\end{array}$ & $\begin{array}{l}\text { Correlated in patients with } \\
\text { alcoholic CP but not in those with } \\
\text { idiopathic CP }\end{array}$ \\
\hline $\begin{array}{l}\text { Sandhu } \\
\text { et al. [36] }\end{array}$ & 2007 & Cambridge & 159 (159 with CP) & $\begin{array}{l}\text { Patients grouped by MRCP; } \\
\text { compared for mortality, exocrine/ } \\
\text { endocrine insufficiency, pain } \\
\text { characteristics, and complications }\end{array}$ & $\begin{array}{l}\text { No correlation with mortality, } \\
\text { exocrine/endocrine insufficiency. } \\
\text { Pain correlated with severity } \\
\text { progression. Correlated with } \\
\text { biliary stricture but not splenic } \\
\text { vein thrombosis }\end{array}$ \\
\hline $\begin{array}{l}\text { Stevens } \\
\text { et al. [39] }\end{array}$ & 2008 & Cambridge & 83 (50 with CP) & $\begin{array}{l}\text { Patients grouped by ERCP; } \\
\text { compared for pancreatic function } \\
\text { and compared to EUS }\end{array}$ & $\begin{array}{l}\text { Correlated to both }[\mathrm{HCO} 3] \text { and } \\
\text { EUS findings }\end{array}$ \\
\hline $\begin{array}{l}\text { Akisik } \\
\text { et al. [40] }\end{array}$ & 2009 & Cambridge & 28 (13 with $\mathrm{CP}$ ) & $\begin{array}{l}\text { Patients grouped by MRCP; } \\
\text { compared for apparent diffusion } \\
\text { coefficient }\end{array}$ & No correlation \\
\hline $\begin{array}{l}\text { Üsküdar } \\
\text { et al. [41] }\end{array}$ & 2009 & $\begin{array}{l}\text { Cambridge } \\
\text { and EUS criteria }\end{array}$ & 43 (24 with CP) & $\begin{array}{l}\text { Patients grouped by ERCP; } \\
\text { compared for EUS findings and } \\
\text { fecal elastase }\end{array}$ & $\begin{array}{l}\text { ERCP correlated to EUS findings. } \\
\text { Fecal elastase not correlated } \\
\text { to imaging }\end{array}$ \\
\hline $\begin{array}{l}\text { Bilgin } \\
\text { et al. [42] }\end{array}$ & 2009 & Cambridge & 103 (82 with CP) & $\begin{array}{l}\text { Patients grouped by MRI/MRCP; } \\
\text { compared for fecal elastase- } 1\end{array}$ & $\begin{array}{l}\text { Correlated to fecal elastase- } 1 \\
(r=-0.496)\end{array}$ \\
\hline $\begin{array}{l}\text { Balci } \\
\text { et al. [43] }\end{array}$ & 2010 & Cambridge & 36 (36 with CP) & $\begin{array}{l}\text { Patients grouped by MRI/MRCP; } \\
\text { compared for exocrine function } \\
\text { (endoscopic HCO3) }\end{array}$ & No Correlation \\
\hline
\end{tabular}


Table 3. (continued)

\begin{tabular}{|c|c|c|c|c|c|}
\hline Author & Year & $\begin{array}{l}\text { System being } \\
\text { validated }\end{array}$ & $\begin{array}{l}\text { Total } \\
\text { (\# with CP), } n\end{array}$ & Method of validation & Result of validation \\
\hline $\begin{array}{l}\text { Hawkins } \\
\text { et al. [44] }\end{array}$ & 2010 & Cambridge & 9 (9 with CP) & $\begin{array}{l}\text { Patients grouped by MRCP; } \\
\text { compared for pancreatic perfusion }\end{array}$ & Correlated to perfusion \\
\hline $\begin{array}{l}\text { Singer } \\
\text { et al. [45] }\end{array}$ & 2010 & $\begin{array}{l}\text { M-ANNHEIM: } \\
\text { staging and } \\
\text { severity index }\end{array}$ & 523 (523 with CP) & $\begin{array}{l}\text { Patients grouped by M-ANNHEIM; } \\
\text { compared for clinical disease } \\
\text { description, monitoring of disease } \\
\text { course, and prognostic value. }\end{array}$ & $\begin{array}{l}\text { Stages correlated with disease } \\
\text { duration. Severity correlated with } \\
\text { disease duration and with } \\
\text { necessity of surgery }\end{array}$ \\
\hline $\begin{array}{l}\text { Takita } \\
\text { et al. [46] }\end{array}$ & 2011 & Cambridge & 12 (12 with $\mathrm{CP})$ & $\begin{array}{l}\text { Patients grouped by CT/US; } \\
\text { compared for outcome of islet } \\
\text { isolation and autotransplant }\end{array}$ & $\begin{array}{l}\text { Correlated to insulin } \\
\text { independence, no correlation } \\
\text { with HbAlc }\end{array}$ \\
\hline $\begin{array}{l}\text { Katsotourchi } \\
\text { et al. [47] }\end{array}$ & 2011 & $\begin{array}{l}\text { M-ANNHEIM : } \\
\text { staging and } \\
\text { severity index }\end{array}$ & $\begin{array}{l}302 \text { patients } \\
(302 \text { with } \mathrm{CP})\end{array}$ & $\begin{array}{l}\text { Patients grouped by M-ANNHEIM } \\
\text { to determine the viability of use }\end{array}$ & $\begin{array}{l}\text { Evaluated patients according to } \\
\text { clinical and severity stages. } \\
\text { Recommended decreasing the } \\
\text { number of stages for better } \\
\text { assessment }\end{array}$ \\
\hline $\begin{array}{l}\text { Kadiyala } \\
\text { et al. [48] }\end{array}$ & 2011 & $\begin{array}{l}\text { M-ANNHEIM: } \\
\text { Clinical feature } \\
\text { score, severity } \\
\text { index, } \\
\text { morphologic } \\
\text { changes }\end{array}$ & 131 (131 with CP) & $\begin{array}{l}\text { Patients classified by M-ANNHEIM; } \\
\text { compared for smoking status and } \\
\text { alcohol intake }\end{array}$ & $\begin{array}{l}\text { Clinical features score and } \\
\text { severity index correlated with } \\
\text { smoking but not with alcohol. } \\
\text { Morphology changes correlated } \\
\text { with smoking and alcohol }\end{array}$ \\
\hline $\begin{array}{l}\text { Bouwense } \\
\text { et al. [49] }\end{array}$ & 2013 & $\begin{array}{l}\text { M-ANNHEIM: } \\
\text { severity index }\end{array}$ & 75 (60 with CP) & $\begin{array}{l}\text { Patients grouped by severity index; } \\
\text { compared for pain thresholds }\end{array}$ & $\begin{array}{l}\text { Severe group had lower pain } \\
\text { threshold than moderate group } \\
\text { and healthy controls }\end{array}$ \\
\hline $\begin{array}{l}\text { Bian } \\
\text { et al. [50] }\end{array}$ & 2013 & $\begin{array}{l}\text { M-ANNHEIM: } \\
\text { unknown } \\
\text { component }\end{array}$ & 53 (36 with CP) & $\begin{array}{l}\text { Patients classified by M-ANNHEIM; } \\
\text { compared for pancreatic flow } \\
\text { rate and FE-1 }\end{array}$ & $\begin{array}{l}\text { Moderately correlated to } \\
\text { pancreatic flow and FE- } 1, \\
r=0.55 \text { and } 0.57, \text { respectively }\end{array}$ \\
\hline $\begin{array}{l}\text { Härteol } \\
\text { et al. [53] }\end{array}$ & 2014 & $\begin{array}{l}\text { M-ANNHEIM: } \\
\text { unknown } \\
\text { component }\end{array}$ & 190 (190 with CP) & $\begin{array}{l}\text { Patients classified by M-ANNHEIM; } \\
\text { compared for duration of disease }\end{array}$ & $\begin{array}{l}\text { Correlated with disease duration. } \\
\text { More severe clinical course } \\
\text { in alcoholic than in } \\
\text { non-alcoholic CP }\end{array}$ \\
\hline $\begin{array}{l}\mathrm{He} \\
\text { et al. [54] }\end{array}$ & 2014 & $\begin{array}{l}\text { M-ANNHEIM: } \\
\text { clinical staging }\end{array}$ & 89 (89 with CP) & $\begin{array}{l}\text { Patients classified by M-ANNHEIM; } \\
\text { pain scores compared during the } \\
2 \text {-year follow-up post endoscopic } \\
\text { therapy }\end{array}$ & $\begin{array}{l}\text { Patients at lower clinical stage } \\
\text { exhibited greater pain relief. } \\
\text { Patients at lower clinical stage had } \\
\text { a higher incidence of post- } \\
\text { endoscopic retrograde } \\
\text { cholangiopancreatography } \\
\text { pancreatitis }\end{array}$ \\
\hline $\begin{array}{l}\text { Hirth } \\
\text { et al. [55] }\end{array}$ & 2015 & $\begin{array}{l}\text { M-ANNHEIM: } \\
\text { severity index }\end{array}$ & 740 (740 with CP) & $\begin{array}{l}\text { Patients classified by severity index; } \\
\text { compared to predict need } \\
\text { for surgery }\end{array}$ & $\begin{array}{l}\text { Useful for monitoring clinical } \\
\text { course and assessing of necessity } \\
\text { of surgery }\end{array}$ \\
\hline
\end{tabular}


Table 3. (continued)

\begin{tabular}{|c|c|c|c|c|c|}
\hline Author & Year & $\begin{array}{l}\text { System being } \\
\text { validated }\end{array}$ & $\begin{array}{l}\text { Total } \\
\text { (\# with CP), n }\end{array}$ & Method of validation & Result of validation \\
\hline $\begin{array}{l}\text { Peixoto } \\
\text { et al. [56] }\end{array}$ & 2015 & Cambridge CT & 28 (28 with CP) & $\begin{array}{l}\text { Patients grouped by CT; compared } \\
\text { for exocrine insufficiency (fecal } \\
\text { elastase- } 1 \text { and Triglyceride C13 } \\
\text { labelled breath test) }\end{array}$ & No correlation \\
\hline $\begin{array}{l}\text { Fujiyama } \\
\text { et al. [58] }\end{array}$ & 2016 & Cambridge & 69 (49 with CP) & $\begin{array}{l}\text { Patients grouped by ERCP; } \\
\text { compared for novel biomarker } \\
\text { (serum WFA+ -M2BP) }\end{array}$ & Correlated to biomarker \\
\hline $\begin{array}{l}\text { Madzak } \\
\text { et al. [60] }\end{array}$ & 2017 & $\begin{array}{l}\text { Cambridge and } \\
\text { M-ANNHEIM: } \\
\text { Clinical staging }\end{array}$ & 104 (82 with CP) & $\begin{array}{l}\text { Patients classified by Cambridge } \\
\text { and M-ANNHEIM; compared for } \\
\text { s-MRI findings and fecal elastase }\end{array}$ & $\begin{array}{l}\text { Fecal elastase negatively } \\
\text { correlated to Cambridge, but no } \\
\text { correlation to M-ANNHEIM. } \\
\text { Pancreatic gland volume } \\
\text { negatively correlated to } \\
\text { Cambridge and M-ANNHEIM. } \\
\text { Remaining parameters had no } \\
\text { correlation }\end{array}$ \\
\hline
\end{tabular}

$\mathrm{CP}$, chronic pancreatitis; ERCP, endoscopic retrograde cholangiopancreatography.

tions to limit disease progression and improve quality of life $[71,72]$.

To improve the clinical management of $\mathrm{CP}$ and reflect up to date advances in the understanding of aetiological and functional sequelae, a classification system based on the key clinical aspects such as pain, pancreatic functional status (exocrine and endocrine), and imaging modalities are desirable $[6,73]$. An effective scoring system would be able to classify and characterise all presentations of CP complications across relevant categories of pain, function (including endocrine function, exocrine function, nutritional status, and bone health) and mechanical (including pancreatic and extra-pancreatic complications) while incorporating explicit aetiological and diagnostic classifications. Complementary to this would be an easy-to-calculate but accurate score, to determine disease severity in meaningful observational or interventional studies as well as to determine patient treatment plans in regular clinical practice.

\section{Acknowledgement}

We would like to thank Trinity College Dublin for providing the support necessary to make this research initiative a success.

\section{Statement of Ethics}

The authors have no ethical conflicts to disclose.

\section{Disclosure Statement}

The authors have no conflicts of interest to declare.

\section{Funding Sources}

This study was supported by an unrestricted grant from the Meath Foundation, Tallaght University Hospital, Dublin 24, Ireland. 


\section{Author Contributions}

A.R. and D.B.O.: participated in the conception and design of the study, analysis and interpretation of data, drafting the article, revised it critically for important intellectual content, and approved the final version of the article. Y.B.: participated in drafting the article, revised it critically for important intellectual content, and approved the final version of the article. F.G., S.K., and J.G.: participated in the analysis and interpretation of data, drafting the article, and approved the final version of the article. D.M. and R.M.: participated in the conception and design of the study, and approved the final version of the article. S.N.D.: participated in revising the article critically for important intellectual content, and approved the final version of the article. K.C.C.: was the supervising co-coordinator for the project and participated in revising the article critically for important intellectual content, and approved the final version of the article.

\section{Appendix}

Search Strategy

1. "Chronic pancreatitis"/exp

2. ([Chronic] NEAR/2 pancreatitis):ti,ab

3. \#1 OR \#2

4. "Disease severity assessment"/exp OR "disease severity"/exp OR “scoring system"/exp OR "diagnosis"/exp OR "diagnostic approach route"/exp

5. ("Chronic pancreatitis" NEAR/5 [severity OR assess* OR Scale* OR score* OR scoring OR degree OR index OR assess* OR predict* OR diagnos* OR grading]):ti,ab

6. \#4 OR \#5

7. "Diagnostic accuracy"/exp OR "diagnostic value"/exp OR "predictive value"/exp OR "prediction"/exp OR "sensitivity and specificity"/exp

8. (Compar* OR evaluat* OR valid* OR reliab* OR accurac* OR value OR predict* OR sensitivity OR specificity):ti,ab

9. \#7 OR \#8

10. \#3 AND \#6 AND \#

\section{References}

1 DiMagno MJ, Dimagno EP. Chronic pancreatitis. Curr Opin Gastroenterol. 2006 Sep; 22(5):487-97.

2 Uomo G. How far are we from the most accurate classification system for chronic pancreatitis? JOP. 2002 May;3(3):62-5.

3 Lankisch PG, Löhr-Happe A, Otto J, Creutzfeldt W. Natural course in chronic pancreatitis. Pain, exocrine and endocrine pancreatic insufficiency and prognosis of the disease. Digestion. 1993;54(3):148-55.

4 Layer P, Yamamoto H, Kalthoff L, Clain JE, Bakken LJ, DiMagno EP. The different courses of early- and late-onset idiopathic and alcoholic chronic pancreatitis. Gastroenterology. 1994 Nov; 107(5):1481-7.

5 Ammann RW, Muellhaupt B; Zurich Pancreatitis Study Group. The natural history of pain in alcoholic chronic pancreatitis. Gastroenterology. 1999 May;116(5):1132-40.

6 Dominguez-Munoz JE, Drewes AM, Lindkvist B, Ewald N, Czakó L, Rosendahl J, et al.; HaPanEU/UEG Working Group. Recommendations from the United European Gastroenterology evidence-based guidelines for the diagnosis and therapy of chronic pancreatitis. Pancreatology. 2018 Dec;18(8):84754.

7 Majumder S, Chari ST. Chronic pancreatitis. Lancet. 2016 May;387(10031):1957-66.

8 Joergensen $M$, Brusgaard K, Crüger DG, Gerdes AM, de Muckadell OB. Incidence, prevalence, etiology, and prognosis of firsttime chronic pancreatitis in young patients: a nationwide cohort study. Dig Dis Sci. 2010 Oct;55(10):2988-98.

9 Schneider A, Löhr JM, Singer MV. The MANNHEIM classification of chronic pancreatitis: introduction of a unifying classification system based on a review of previous classifications of the disease. J Gastroenterol. 2007 Feb;42(2):101-19.

10 Sarner M, Cotton PB. Classification of pancreatitis. Gut. 1984 Jul;25(7):756-9.

11 Catalano MF, Sahai A, Levy M, Romagnuolo J, Wiersema M, Brugge W, et al. EUS-based criteria for the diagnosis of chronic pancreatitis: the Rosemont classification. Gastrointest Endosc. 2009 Jun;69(7):1251-61.

12 Etemad B, Whitcomb DC. Chronic pancreatitis: diagnosis, classification, and new genetic developments. Gastroenterology. $2001 \mathrm{Feb}$; 120(3):682-707.

13 Gupte A, Goede D, Tuite R, Forsmark CE. Chronic pancreatitis. BMJ. 2018 Jun;361: k2126.

14 Büchler MW, Martignoni ME, Friess H, Malfertheiner P. A proposal for a new clinical classification of chronic pancreatitis. BMC Gastroenterol. 2009 Dec;9(1):93.

15 Stern I, Roberts-Thomson IC, Hansky J. Correlation between pancreatic polypeptide response to secretin and ERCP findings in chronic pancreatitis. Gut. 1982 Mar;23(3): 235-8.

16 Catalano MF, Lahoti S, Geenen JE, Hogan WJ. Prospective evaluation of endoscopic ultrasonography, endoscopic retrograde pancreatography, and secretin test in the diagnosis of chronic pancreatitis. Gastrointest Endosc. 1998 Jul;48(1):11-7.

17 Gullo L, Ventrucci M, Tomassetti P, Migliori M, Pezzilli R. Fecal elastase 1 determination in chronic pancreatitis. Dig Dis Sci. 1999 Jan; 44(1):210-3.

18 Ramesh $\mathrm{H}$. Proposal for a new grading system for chronic pancreatitis: the ABC system. J Clin Gastroenterol. 2002 Jul;35(1):67-70.
19 Bagul A, Siriwardena AK. Evaluation of the Manchester classification system for chronic pancreatitis. JOP. 2006 Jul;7(4):390-6.

20 Orlikov GA, Pliavinia IA, Pokrotnieks IIa, Seleznev IV. [Ultrasonographic assessment of chronic pancreatitis severity. Pancreatic index]. Ter Arkh. 2007;79(2):48-51.

21 Naniwadekar A, Ellis R, Gennings C, Sanyal A, Vachhani R, BouHaidar D, et al. CP Severity Index: A reliable scoring system to assess severity and progression of chronic pancreatitis. Gastoenterol. 2011;140(5):S545 .

22 He D, Matthews S, Kalloo A, Hutfless S. Mining high-dimensional administrative claims data to predict early hospital readmissions. J Am Med Inform Assoc. 2014 Mar-Apr;21(2): 272-9.

23 Beyer G, Mahajan UM, Budde C, Bulla TJ, Kohlmann T, Kuhlmann L, et al. Development and Validation of a Chronic Pancreatitis Prognosis Score in 2 Independent Cohorts. Gastroenterology. 2017 Dec;153(6):15441554.e2.

24 Jones SN, Lees WR, Frost RA. Diagnosis and grading of chronic pancreatitis by morphological criteria derived by ultrasound and pancreatography. Clin Radiol. 1988 Jan;39(1): 43-8.

25 Bozkurt T, Braun U, Leferink S, Gilly G, Lux G. Comparison of pancreatic morphology and exocrine functional impairment in patients with chronic pancreatitis. Gut. 1994 Aug;35(8):1132-6.

26 Yasuda M, Ito T, Oono T, Kawabe K, Kaku T, Igarashi $\mathrm{H}$, et al. Fractalkine and TGF- $\beta 1$ levels reflect the severity of chronic pancreatitis in humans. World J Gastroenterol. 2008 Nov; 14(42):6488-95. 
27 Akisik MF, Aisen AM, Sandrasegaran K, Jennings SG, Lin C, Sherman S, et al. Assessment of chronic pancreatitis: utility of diffusionweighted MR imaging with secretin enhancement. Radiology. 2009 Jan;250(1):103-9.

28 Stevens T, Berk MP, Lopez R, Chung YM, Zhang R, Parsi MA, et al. Lipidomic profiling of serum and pancreatic fluid in chronic pancreatitis. Pancreas. 2012 May;41(4):518-22.

29 Bahuva R, Walsh RM, Kapural L, Stevens T. Morphologic abnormalities are poorly predictive of visceral pain in chronic pancreatitis. Pancreas. 2013 Jan;42(1):6-10.

30 Itoh $\mathrm{H}$, Shimono R, Hamamoto K. Evaluation of common bile duct stenosis in chronic pancreatitis using cholescintigraphy. Eur J Nucl Med. 1988;14(3):137-40.

31 Nagai K, Iguchi K, Yanaihara N. Plasma lipase, C-peptide reactivity and human pancreatic polypeptide responses after ingestion of elemental diet in patients with chronic pancreatitis. Gastroenterol Jpn. 1993 Jun;28(3) 401-5.

32 von Tirpitz C, Glasbrenner B, Mayer D, Malfertheiner P, Adler G. Comparison of different endocrine stimulation tests in nondiabetic patients with chronic pancreatitis. Hepatogastroenterology. 1998 Jul-Aug;45(22):1111-6.

33 Al-Eryani S, Duris I, Huorka M, Payer J, Kratochvilova $\mathrm{H}$, Ondrejka P. Plasma gastrin levels in alcoholic and idiopathic chronic pancreatitis patients free from Helicobacter pylori infection. Ann Saudi Med. 2001 Jan-Mar; 21(1-2):9-12.

34 Mann ST, Stracke H, Lange U, Klör HU, Teichmann J. Alterations of bone mineral density and bone metabolism in patients with various grades of chronic pancreatitis. Metabolism. 2003 May;52(5):579-85

35 Maartense S, Ledeboer M, Masclee AA. Chronic pancreatitis: relation between function and morphology. Dig Liver Dis. 2004 Jan; 36(1):61-7.

36 Sandhu BS, Hackworth WA, Stevens S, Bouhaidar DS, Zfass AM, Sanyal AJ. Recurrent flares of pancreatitis predict development of exocrine insufficiency in chronic pancreatitis Clin Gastroenterol Hepatol. 2007 Sep;5(9): 1085-91.

37 Teichmann J, Mann ST, Stracke H, Lange U, Hardt PD, Klör HU, et al. Alterations of vitamin D3 metabolism in young women with various grades of chronic pancreatitis. Eur J Med Res. 2007 Aug;12(8):347-50

38 Bilgin M, Bilgin S, Balci NC, Momtahen AJ, Bilgin Y, Klör HU, et al. Magnetic resonance imaging and magnetic resonance cholangiopancreatography findings compared with fecal elastase 1 measurement for the diagnosis of chronic pancreatitis. Pancreas. 2008 Jan, 36(1):e33-9.

39 Stevens T, Conwell DL, Zuccaro G Jr, Vargo JJ, Dumot JA, Lopez R. Comparison of endoscopic ultrasound and endoscopic retrograde pancreatography for the prediction of pancreatic exocrine insufficiency. Dig Dis Sci. 2008 Apr;53(4):1146-51.
40 Akisik MF, Sandrasegaran K, Jennings SG Aisen AM, Lin C, Sherman S, et al. Diagnosis of chronic pancreatitis by using apparent diffusion coefficient measurements at 3.0-T MR following secretin stimulation. Radiology. 2009 Aug;252(2):418-25.

41 Usküdar O, Oğuz D, Akdoğan M, Altiparmak E, Sahin B. Comparison of endoscopic retrograde cholangiopancreatography, endoscopic ultrasonography, and fecal elastase 1 in chronic pancreatitis and clinical correlation. Pancreas. 2009 Jul;38(5):503-6.

42 Bilgin M, Balci NC, Momtahen AJ, Bilgin Y, Klör HU, Rau WS. MRI and MRCP findings of the pancreas in patients with diabetes mellitus: compared analysis with pancreatic exocrine function determined by fecal elastase 1 . J Clin Gastroenterol. 2009 Feb;43(2):165-70.

43 Balci NC, Smith A, Momtahen AJ, Alkaade S, Fattahi R, Tariq S, et al. MRI and S-MRCP findings in patients with suspected chronic pancreatitis: correlation with endoscopic pancreatic function testing (ePFT). J Magn Reson Imaging. 2010 Mar;31(3):601-6.

44 Hawkins P, Balci N, Burton F, Alkaade S, Choueiri N, Forrest S, et al. M1378 Progressive Changes of Altered Perfusion by Fast 3D Dynamic Contrast-Enhanced MR Imaging Pre- And Post-Secretin Seen With Increasing Changes of Chronic Pancreatitis on MRCP. Gastroenterology. 2010;138(5):S-392.

45 Singer M, Maissonneuve P, Loehr M, Schneider A. Proposal of a New Classification System of Chronic Pancreatitis. Pancreatology. 2010;10(S1): 16

46 Takita M, Naziruddin B, Matsumoto S, Noguchi $\mathrm{H}$, Shimoda $\mathrm{M}$, Chujo D, et al. Implication of pancreatic image findings in total pancreatectomy with islet autotransplantation for chronic pancreatitis. Pancreas. 2011 Jan; 40(1):103-8.

47 Katsotourchi A, Frulloni L, Amodio A, Viaro T, Tumelero T, Pellicciari M, et al. Evaluation of M-ANNHEIM classification in an Italian series of patients suffering from chronic pancreatitis. Dig Liver Dis. 2011;43(S3):S144.

48 Kadiyala V, Banks P, Lee L, Rosenblum J, Paulo J, Sainani N et al. Cigarette smoking impacts chronic pancreatitis clinical feature score, severity index and imaging severity. Am J Gastroenterol. 2011;106(S2):S59-60.

49 Bouwense SA, Olesen SS, Drewes AM, Frøkjær JB, van Goor $\mathrm{H}$, Wilder-Smith $\mathrm{OH}$. Is altered central pain processing related to disease stage in chronic pancreatitis patients with pain? An exploratory study. PLoS One. 2013;8(2):e55460.

50 Bian Y, Wang L, Chen C, Lu JP, Fan JB, Chen SY, et al. Quantification of pancreatic exocrine function of chronic pancreatitis with secretin-enhanced MRCP. World J Gastroenterol. 2013 Nov; 19(41):7177-82.

51 Burton S, Kadiyala V, Suleiman S, Lee L, Banks P, Conwell D. Validation of $\mathrm{M}$ ANNHEIM imaging grade for use with MRI/ MRCP in chronic pancreatitis. Pancreatology. 2013;13(2):e8
52 Fernández Cano F, Romero Ordóñez $M$, González Bárcenas M, Rivera Irigoin R, López Vega M, Rosales Zábal J, et al. Do endoscopic ultrasound provides information in evaluating exocrine pancreatic insufficiency in chronic pancreatitis? Pancreatology. 2013. 13(4 S1):e16.

53 Härteol N, Weiss C, Ebert M, Schneider A Comparison of the clinical parameters of the $\mathrm{m}$-annheim classification system in patients with alcoholic and non-alcoholic chronic pancreatitis. Pancreatology. 2014;14(3S1):S40-1.

54 He YX, Xu HW, Sun XT, Ye Z, Wang W, Lai $\mathrm{XW}$, et al. Endoscopic management of earlystage chronic pancreatitis based on $\mathrm{M}$ ANNHEIM classification system: a prospective study. Pancreas. 2014 Aug;43(6):829-33.

55 Hirth M, Kolb S, Weiß C, Rückert F, Wilhelm T, Hardt P, et al. Who needs to be operated? Prognostic evaluation of the necessity of surgery in chronic pancreatitis according to the M-ANNHEIM classification. Pancreatology. 2015;15(3):S71.

56 Peixoto A, Silva M, Boas F, Rodrigues-Pinto E, Pereira P, Macedo G. Concordance between imaging and functional studies in the diagnosis of pancreatic exocrine insufficiency. Pancreatology. 2015;15(3):S80.

57 Gecov P, Siminkovitch S, Vladimirov B, Nedelkov G, Kovacheva-Slavova G, Golemanov B. Evaluation of secretin-enhanced MRCP in chronic pancreatitis. Pancreas. 2016;45(10): 1506.

58 Fujiyama T, Ito T, Ueda K, Tachibana Y, Yasunaga $\mathrm{K}$, Miki M, et al. Serum levels of Wisteria floribunda agglutinin-positive Mac-2 binding protein reflect the severity of chronic pancreatitis. J Dig Dis. 2017 May;18(5):3028

59 Zhao ZH, Hu LH, Ren HB, Zhao AJ, Qian YY, Sun XT, et al. Incidence and risk factors for post-ERCP pancreatitis in chronic pancreatitis. Gastrointest Endosc. 2017 Sep;86(3):519524.e1.

60 Madzak A, Olesen SS, Haldorsen IS, Drewes AM, Frøkjær JB. Secretin-stimulated MRI characterization of pancreatic morphology and function in patients with chronic pancreatitis. Pancreatology. 2017 Mar - Apr;17(2): 228-36.

61 Blamey SL, Imrie CW, O’Neill J, Gilmour WH, Carter DC. Prognostic factors in acute pancreatitis. Gut. 1984 Dec;25(12):1340-6.

62 Ranson JH, Rifkind KM, Turner JW. Prognostic signs and nonoperative peritoneal lavage in acute pancreatitis. Surg Gynecol Obstet. 1976 Aug;143(2):209-19.

63 Jairath V, Zou G, Parker CE, Macdonald JK, Mosli MH, Khanna R, et al. Systematic review and meta-analysis: placebo rates in induction and maintenance trials of ulcerative colitis. Crohn's Colitis. 2016 May; 10(5):607-18.

64 Wilcox CM, Yadav D, Ye T, Gardner TB, Gelrud A, Sandhu BS, et al. Chronic pancreatitis pain pattern and severity are independent of abdominal imaging findings. Clin Gastroenterol Hepatol. 2015 Mar;13(3):552-60. 
65 Duggan SN, Ní Chonchubhair HM, Lawal O, O'Connor DB, Conlon KC. Chronic pancreatitis: A diagnostic dilemma. World J Gastroenterol. 2016 Feb;22(7):2304-13.

66 Hollemans RA, Hallensleben ND, Mager DJ, Kelder JC, Besselink MG, Bruno MJ, et al.; Dutch Pancreatitis Study Group. Pancreatic exocrine insufficiency following acute pancreatitis: systematic review and study level meta-analysis. Pancreatology. 2018 Apr; 18(3):253-62.

67 Duggan SN, Smyth ND, Murphy A, Macnaughton D, O'Keefe SJ, Conlon KC. High prevalence of osteoporosis in patients with chronic pancreatitis: a systematic review and meta-analysis. Clin Gastroenterol Hepatol. $2014 \mathrm{Feb} ; 12(2): 219-28$.
68 Duggan SN, Ewald N, Kelleher L, Griffin O, Gibney J, Conlon KC. The nutritional management of type $3 \mathrm{c}$ (pancreatogenic) diabetes in chronic pancreatitis. Eur J Clin Nutr. 2017 Jan;71(1):3-8.

69 Ammann RW, Akovbiantz A, Largiader F, Schueler G. Course and outcome of chronic pancreatitis. Longitudinal study of a mixed medical-surgical series of 245 patients. Gastroenterology. 1984 May;86(5 Pt 1):820-8.

70 Nealon WH, Matin S. Analysis of surgical success in preventing recurrent acute exacerbations in chronic pancreatitis. Ann Surg. 2001 Jun;233(6):793-800.

71 Ahmed Ali U, Issa Y, Bruno MJ, van Goor H, van Santvoort H, Busch OR, et al.; Dutch Pancreatitis Study Group. Early surgery versus optimal current step-up practice for chronic pancreatitis (ESCAPE): design and rationale of a randomized trial. BMC Gastroenterol. 2013 Mar;13(1):49.

72 Diener MK, Hüttner FJ, Kieser M, Knebel P, Dörr-Harim C, Distler M, et al.; ChroPac Trial Group. Partial pancreatoduodenectomy versus duodenum-preserving pancreatic head resection in chronic pancreatitis: the multicentre, randomised, controlled, doubleblind ChroPac trial. Lancet. 2017 Sep; 390(10099):1027-37.

73 Whitcomb DC, Frulloni L, Garg P, Greer JB, Schneider A, Yadav D, et al. Chronic pancreatitis: an international draft consensus proposal for a new mechanistic definition. Pancreatology. 2016 Mar-Apr;16(2):218-24. 